\title{
Control of Xiphinema index Populations by Fallow Plants Under Greenhouse and Field Conditions
}

\author{
Laure Villate, Elisa Morin, Gérard Demangeat, Maarten Van Helden, and Daniel Esmenjaud
}

First author: INRA, UMR 1099 BiO3P F-35653 Le Rheu, France; first, second, and fourth authors: Bordeaux Sciences Agro, University of Bordeaux, 1 Cours du Général de Gaulle, ISVV, F-33170 Gradignan, France; third author: INRA, UMR1131 Santé de la Vigne et Qualité du Vin, F-68000 Colmar, France, and Université de Strasbourg, UMR1131, F-68000 Colmar, France; and fifth author: INRA, UMR1355 ISA, F-06903 Sophia-Antipolis, France, CNRS, UMR6243 ISA, F-06903 Sophia-Antipolis, France, and Université de Nice SophiaAntipolis, UMR ISA, F-06903 Sophia-Antipolis, France.

Current address for L. Villate: INRA, UMR1202 BioGeCo, F-33612 Cestas, France, and University of Bordeaux, BIOGECO, UMR1202, F-33400 Talence, France.

Accepted for publication 14 February 2012.

\begin{abstract}
Villate, L., Morin, E., Demangeat, G., Van Helden, M., and Esmenjaud, D. 2012. Control of Xiphinema index populations by fallow plants under greenhouse and field conditions. Phytopathology 102:627-634.

The dagger nematode Xiphinema index has a high economic impact in vineyards by direct pathogenicity and above all by transmitting the Grapevine fanleaf virus (GFLV). Agrochemicals have been largely employed to restrict the spread of GFLV by reducing $X$. index populations but are now banned. As an alternative to nematicides, the use of fallow plants between two successive vine crops was assessed. We selected plant species adapted to vineyard soils and exhibiting negative impact on nematodes and we evaluated their antagonistic effect on $X$. index in greenhouse using artificially infested soil, and in naturally infested vineyard conditions. The screening was conducted with plants belonging
\end{abstract}

ABSTRACT to the families Asteraceae (sunflower, marigold, zinnia, and nyjer), Poaceae (sorghum and rye), Fabaceae (white lupin, white melilot, hairy vetch, and alfalfa), Brassicaceae (rapeseed and camelina), and Boraginaceae (phacelia). In the greenhouse controlled assay, white lupin, nyjer, and marigold significantly reduced $X$. index populations compared with that of bare soil. The vineyard assay, designed to take into account the aggregative pattern of $X$. index distribution, revealed that marigold and hairy vetch are good candidates as cover crops to reduce $X$. index populations in vineyard. Moreover, this original experimental design could be applied to manage other soilborne pathogens.

Additional keywords: allelopathy, nematicidal plants, sampling design, Vitis vinifera.
The dagger nematode Xiphinema index is economically the major virus vector in viticulture. It transmits exclusively the Grapevine fanleaf virus (GFLV), the most detrimental grapevine virus disease worldwide, responsible for the fanleaf disease $(6,9,22)$. GFLV is transmitted from grapevine to grapevine while $X$. index feeds on growing root tips. GFLV particles are retained over long periods at specific sites within its feeding apparatus $(12,36)$. Fanleaf disease has a sustained impact in vineyards where it is established because of the survival of $X$. index between two successive grapevine crops $(6,12)$. Indeed, complete virus control is very difficult as a few surviving viruliferous $X$. index may be sufficient to infect grapevine plants and reinitiate a new GFLV outbreak $(12,35)$. So far, control strategies relied mainly on soil disinfection to reduce $X$. index numbers between two successive grapevine crops $(28,35)$. However, chemical treatments are effective only in the upper layers (0 to $40 \mathrm{~cm}$ ) of the soil (37), whereas the highest densities of $X$. index usually occur deeper (40 to $110 \mathrm{~cm}$ depth), where many thin grape roots are present in nonirrigated vineyards $(14,15,39)$. Moreover, nematodes can survive and retain GFLV in unfavorable conditions for many years (12). Therefore, nematicides have limited efficiency against $X$. index. Moreover, the use of nematicides is being prohibited in an

Corresponding author: M. van Helden

E-mail address: maarten.vanhelden@agro-bordeaux.fr

http://dx.doi.org/10.1094/PHYTO-01-12-0007

(C) 2012 The American Phytopathological Society increasing number of countries, because of their adverse environmental effects and health risks (5). Devitalization using systemic herbicides can be used on GFLV-infected grapevines before uprooting them to destroy roots which could serve as virus and nematode reservoirs, thus delaying contamination of replants (13). Nowadays, the only alternative method to effectively reduce $X$. index numbers is a careful removal of root debris followed by a prolonged fallow period (at least 7 years) $(12,14)$. But due to the limits of these cultural practices, developing alternative control strategies is essential. Among them, plants with an antagonistic effect on the vector $X$. index may be a suited alternative before replanting vines in naturally fanleaf-infested grapevine plots.

The antagonistic effect of some plant species against nematodes aroused an increasing interest during the last decades $(2,7,19$, 20,34). Numerous plant species release compounds that can be biocide or interfere with the life cycle of the nematode $(10,18,33)$, whereas others are simply nonhosts (30). Various plant species, belonging to diverse botanical families, have been reported to contain or release nematicidal compounds $(10,17,18)$. In agriculture, some of these antagonistic plants are used to control nematodes, either in crop rotations, intercropping, as cover crops or as green manures (30). Most of the plants with a nematicidal effect belong to the botanical families Asteraceae (marigold [Tagetes minuta L.], cosmos [Cosmos bipinnatus L.], firewheel [Gaillardia picta L.], and zinnia [Zinnia elegans L.] among others) $(8,16)$ and Brassicaceae (like rapeseed [Brassica napus L.], white mustard [Sinapis alba L.], and radish [Raphanus sativus L.]) (19). 
The main plant species previously evaluated for their antagonistic effect against $X$. index are listed in Table 1 . The nematicidal activity of cosmos and white lupin (Lupinus albus L.), used as green manure, was also demonstrated against $X$. americanum (1). Those studies revealed a large number of plant species showing a potential antagonistic effect against $X$. index in controlled or in semifield conditions. Confirming the effect of these and new plants in field conditions is indispensable. Indeed, in nonirrigated vineyards, the main challenge of alternative methods for $X$. index control is to reach the deep soil layers where most of the nematodes live. Moreover, vineyard soils often present adverse agronomic characteristics (high sensitivity to water stress, low organic matter and nitrogen content, and high copper content) making them poorly suited for the development of most plants other than grapevine. This observation underlines the need to assess the antagonistic effect of plants against $X$. index under both controlled and field conditions.

Usually, the antagonistic effect of a plant species against a nematode pest, or more widely the effect of a control method against a pest or a pathogen, can be evaluated by comparing final toward initial population levels. However, X. index populations display a significant aggregative pattern in vineyards, with patches of 6 to $8 \mathrm{~m}$ diameter, together with a significant neighborhood structure of nematode densities (39). Therefore, sampling to accurately estimate nematode densities within fields needs to be performed on a very dense grid and at a depth of 50 to $80 \mathrm{~cm}$ (within soil layers that most often contain the highest density of thin growing grapevine roots) and is thus very labor and time consuming. Moreover, it requires heavy machinery (excavating machine) and risks profoundly disturbing the existing nematode populations. Consequently, a preliminary sampling before a field test could interfere with the conclusions of any further field plant evaluation. So, testing antagonistic plants against $X$. index needs an adequate protocol and a design minimizing the cost of sampling and maximizing information about nematode numbers.

The aim of this paper is to (i) evaluate 11 plant species for their antagonistic effect against $X$. index under artificial inoculation in controlled greenhouse conditions, and (ii) assess the antagonistic effect of four plant species under grapevine field conditions with a novel design taking into account the constraint of the aggre- gative spatial pattern of the nematodes, as well as to assess the ability of these four plants to develop roots deep enough to reach nematodes.

\section{MATERIALS AND METHODS}

Identification of the selected plants. We chose plant species from families and species previously evaluated (Table 1) and/or considered as potentially adapted to pedoclimatic constraints of the Bordeaux vineyard. Plant seeds were provided by JouffrayDrillaud Seeds Company (Cissé, France) except for Tagetes minuta provided by Phytosem (Gap, France).

The two trials included 13 selected plant species (Table 2) belonging to five botanical families. Among the plants evaluated in the assay conducted in the greenhouse, four plant species belong to the family Asteraceae: zinnia (Zinnia elegans Jacq.), for which Insunza et al. (23) showed an in vitro mortality of $X$. index with aqueous extracts from roots; marigold (Tagetes minuta L.), which exhibits a nematicidal effect against several nematode species and particularly root-lesion $(17,29)$ and root-knot (26) nematodes; sunflower (Helianthus annuus L. 'Impario') for its abundant root system; and nyjer (Guizotia abyssinica (L.f.) Cass. Given the significant antagonistic effect of many Brassicaceae species against $X$. index observed by Aballay et al. (2-4, Table 1), using extracts or green manure, we chose to include rapeseed (Brassica napus L. 'Parapluie') and camelina (Camelina sativa L.). Phacelia (Phacelia tanacetifolia Benth.), a plant from the family Boraginaceae, already reported for its nematicidal effect against the beet cyst nematode Heterodera schachtii (21), was also included. We furthermore tested two Fabaceae species: the white lupin (Lupinus albus L. 'Clovis'), chosen for its significant antagonistic effect as cover crop against $X$. americanum, another nepovirus vector (1) and white melilot (Melilotus albus Medik). Lastly, two Poaceae species were also evaluated: sorghum (Sorghum vulgare Pers. 'Vercors') for its abundant root system and resistance to water stress and rye (Secale cereale L. 'Tonus'). The experiment also included the grapevine (Vitis vinifera L. 'Cabernet Sauvignon') as a positive control and the bare soil as a reference control. Grapevine plants were micropropagated in vitro and acclimatized in a greenhouse (38).

TABLE 1. Plant species previously evaluated for their antagonistic effect against Xiphinema index

\begin{tabular}{|c|c|c|c|c|c|c|}
\hline Family & Common name & Species & Conditions & Application form & Effect & Reference \\
\hline \multirow[t]{8}{*}{ Asteraceae } & Chamomile & Chamomilla recutita & In vitro & Aqueous extracts from flowers & Significant negative & 23 \\
\hline & Cosmos & Cosmos bipinnatus & In vitro & Aqueous extracts (tops) & Significant negative & 23 \\
\hline & Cosmos & Cosmos bipinnatus & Field & Green manure & Nonsignificant & 2 \\
\hline & Firewheel & Gaillardia picta & Field & Green manure & Nonsignificant & 2 \\
\hline & Pot marigold & Calendula officinalis & Field & Green manure & Nonsignificant & 2 \\
\hline & Marigold & Tagetes patula & Field & Green manure & Nonsignificant & 2 \\
\hline & Zinnia & Zinnia elegans & In vitro & Aqueous extracts (roots) & Significant negative & 23 \\
\hline & Zinnia & Zinnia elegans & Field & Green manure & Nonsignificant & 2 \\
\hline \multirow[t]{4}{*}{ Brassicaceae } & Brown mustard & Brassica juncea & Greenhouse & Green manure & Significant negative & 4 \\
\hline & Rapeseed & Brassica napus & Greenhouse & Green manure & Nonsignificant & 4 \\
\hline & Rapeseed & Brassica napus & Field & Green manure & Significant negative & 2 \\
\hline & Radish & Raphanus sativus & Field & Extracts & Significant negative & 3 \\
\hline \multirow[t]{2}{*}{ Chenopodiaceae } & Wormseed & Chenopodium ambrosioides & In vitro & Aqueous extracts (tops and roots) & Significant negative & 23 \\
\hline & Wormseed & Chenopodium ambrosioides & Greenhouse & Green manure & Nonsignificant & 4 \\
\hline Elaeocarpaceae & Maquei & Aristotelia chilensis & Field & Extracts & Significant negative & 3 \\
\hline Fabaceae & White lupin & Lupinus albus & Field & Green manure & Nonsignificant & 2 \\
\hline \multirow[t]{4}{*}{ Lamiaceae } & Lemon balm & Melissa officinalis & Field & Extracts & Significant negative & 3 \\
\hline & Pennyroyal & Mentha pulegium & Field & Extracts & Significant negative & 3 \\
\hline & Thyme & Thymus vulgaris & Field & Green manure & Nonsignificant & 2 \\
\hline & Thyme & Thymus vulgaris & Greenhouse & Green manure & Nonsignificant & 4 \\
\hline Oxalidaceae & Wood sorrel & Oxalis rosea & In vitro & Aqueous extracts (whole plant) & Significant negative & 23 \\
\hline Plantaginaceae & Greater plantain & Plantago major & Field & Extracts & Significant negative & 3 \\
\hline \multirow[t]{2}{*}{ Rutaceae } & Common rue & Ruta graveolens & In vitro & Aqueous extracts (leaves) & Significant negative & 31 \\
\hline & Rue & Ruta graveolens & Greenhouse & Green manure & Nonsignificant & 4 \\
\hline \multirow[t]{2}{*}{ Solanaceae } & Pepper & Capsicum annиит & In vitro & Aqueous extracts (pods) & Significant negative & 32 \\
\hline & Vestia & Vestia lycioides & In vitro & Aqueous extracts (leaves) & Significant negative & 23 \\
\hline
\end{tabular}


For the vineyard assay, we chose two species within plants showing an antagonistic effect in controlled conditions: marigold (T. minuta L.) and white lupin (L. albus 'Clovis'). We also added two other Fabaceae crops, alfalfa (Medicago sativa L. 'Timbale') and hairy vetch (Vicia villosa L. 'Savane'), because of their ability to develop in vineyard soils.

Production of nematodes. Fig (Ficus carica) plants were used to establish rearings of aviruliferous $X$. index in the greenhouse. Fig plants were produced from green cuttings cultivated in a climatic chamber under controlled temperature $\left(26^{\circ} \mathrm{C}\right)$ and light (16 h) conditions. About 500 aviruliferous $X$. index were used to initiate rearings with a rooted fig cutting in 10-liter pots containing loess $(1 / 3)$ and sand $(2 / 3, \mathrm{wt} / \mathrm{wt})$ as artificial substrate. Fig plants were cultivated under controlled conditions $\left(20\right.$ to $25^{\circ} \mathrm{C}$ and $16 \mathrm{~h}$ daylight) in the greenhouse.
Greenhouse assay. The assay in controlled conditions was carried out in a greenhouse with temperatures ranging from 15 to $25^{\circ} \mathrm{C}$. Additional light (6 a.m. to 8 p.m.) was provided by SONT lamps. We performed the sowing on 28 August 2006 in 3-liter containers (10 replicates per plant species) filled with steam-sterilized soil taken from a Bordeaux vineyard plot. This soil was previously sterilized $\left(30 \mathrm{~min}\right.$ at $120^{\circ} \mathrm{C}$ ) to kill any endogenous nematodes. Plant containers were randomly distributed in a single-block design and drip irrigated automatically every day. Finally, on 5 September 2006, we inoculated 200 X. index individuals per container into a 5 -cm deep hole. Plants were in the seedling stage.

Vineyard assay. This assay was performed in a naturally highly GFLV-infected commercial vineyard located in the Bordeaux region (France). This plot was uprooted in March 2007

TABLE 2. Plants used for the two experimental procedures

\begin{tabular}{|c|c|c|c|c|c|c|}
\hline Family & Common name & Species & $\begin{array}{l}\text { Evaluation c } \\
\text { the preser }\end{array}$ & $\begin{array}{l}\text { ndition in } \\
\text { study }\end{array}$ & Selection criteria & Reference \\
\hline Asteraceae & $\begin{array}{l}\text { Marigold } \\
\text { Nijer } \\
\text { Sunflower } \\
\text { Zinnia }\end{array}$ & $\begin{array}{l}\text { Tagetes minuta L. } \\
\text { Guizotia abyssinica L.f. } \\
\text { Helianthus annuus L. 'Impario' } \\
\text { Zinnia elegans Jacq. }\end{array}$ & $\begin{array}{l}\text { Greenhouse } \\
\text { Greenhouse } \\
\text { Greenhouse } \\
\text { Greenhouse }\end{array}$ & Vineyard & $\begin{array}{l}\text { Nematicidal effect against a lot of nematode species } \\
\text { Ability to develop in vineyard soils } \\
\text { Abundant root system } \\
\text { Negative effect on } X \text {. index }\end{array}$ & $\begin{array}{l}16,25,28 \\
\text { nd } \\
\text { nd } \\
22\end{array}$ \\
\hline Brassicaceae & $\begin{array}{l}\text { Rapeseed } \\
\text { Camelina }\end{array}$ & $\begin{array}{l}\text { Brassica napus L. 'Parapluie' } \\
\text { Camelina sativa } \mathrm{L} .\end{array}$ & $\begin{array}{l}\text { Greenhouse } \\
\text { Greenhouse }\end{array}$ & & $\begin{array}{l}\text { Negative effect of many Brassicacae species } \\
\text { against } X \text {. index (extracts or green mature) }\end{array}$ & $2,3,4$ \\
\hline Boraginaceae & Phacelia & Phacelia tanacetifolia Benth. & Greenhouse & & Nematicidal effect against cyst nematodes & 20 \\
\hline Fabaceae & $\begin{array}{l}\text { White lupine } \\
\text { White melilot } \\
\text { Alfalfa } \\
\text { Hairy vetch }\end{array}$ & $\begin{array}{l}\text { Lupinus albus } \mathrm{L} \text {. 'Clovis' } \\
\text { Melilotus albus Medik. } \\
\text { Medicago sativa L. 'Timbale' } \\
\text { Vicia villosa } \text { Brot. 'Savane' }\end{array}$ & $\begin{array}{l}\text { Greenhouse } \\
\text { Greenhouse }\end{array}$ & $\begin{array}{l}\text { Vineyard } \\
\text { Vineyard } \\
\text { Vineyard }\end{array}$ & $\begin{array}{l}\text { Negative effect against } X \text {. americanum (cover crop) } \\
\text { Ability to develop in vineyard soils } \\
\text { Ability to develop in vineyard soils } \\
\text { Ability to develop in vineyard soils }\end{array}$ & $\begin{array}{c}1 \\
\text { nd } \\
\text { nd } \\
\text { nd }\end{array}$ \\
\hline Poaceae & $\begin{array}{l}\text { Sorghum } \\
\text { Rye }\end{array}$ & $\begin{array}{l}\text { Sorghum vulgare Pers. 'Vercors' } \\
\text { Secale cereale L. 'Tonus' }\end{array}$ & $\begin{array}{l}\text { Greenhouse } \\
\text { Greenhouse }\end{array}$ & & $\begin{array}{l}\text { Abundant root system and resistance to water stress } \\
\text { Abundant root system and resistance to water stress }\end{array}$ & $\begin{array}{l}\text { nd } \\
\text { nd }\end{array}$ \\
\hline Vitaceae & Grapevine & $\begin{array}{l}\text { Vitis vinifera } \mathrm{L} \text {. 'Cabernet } \\
\text { Sauvignon' }\end{array}$ & Greenhouse & & Positive control & \\
\hline
\end{tabular}

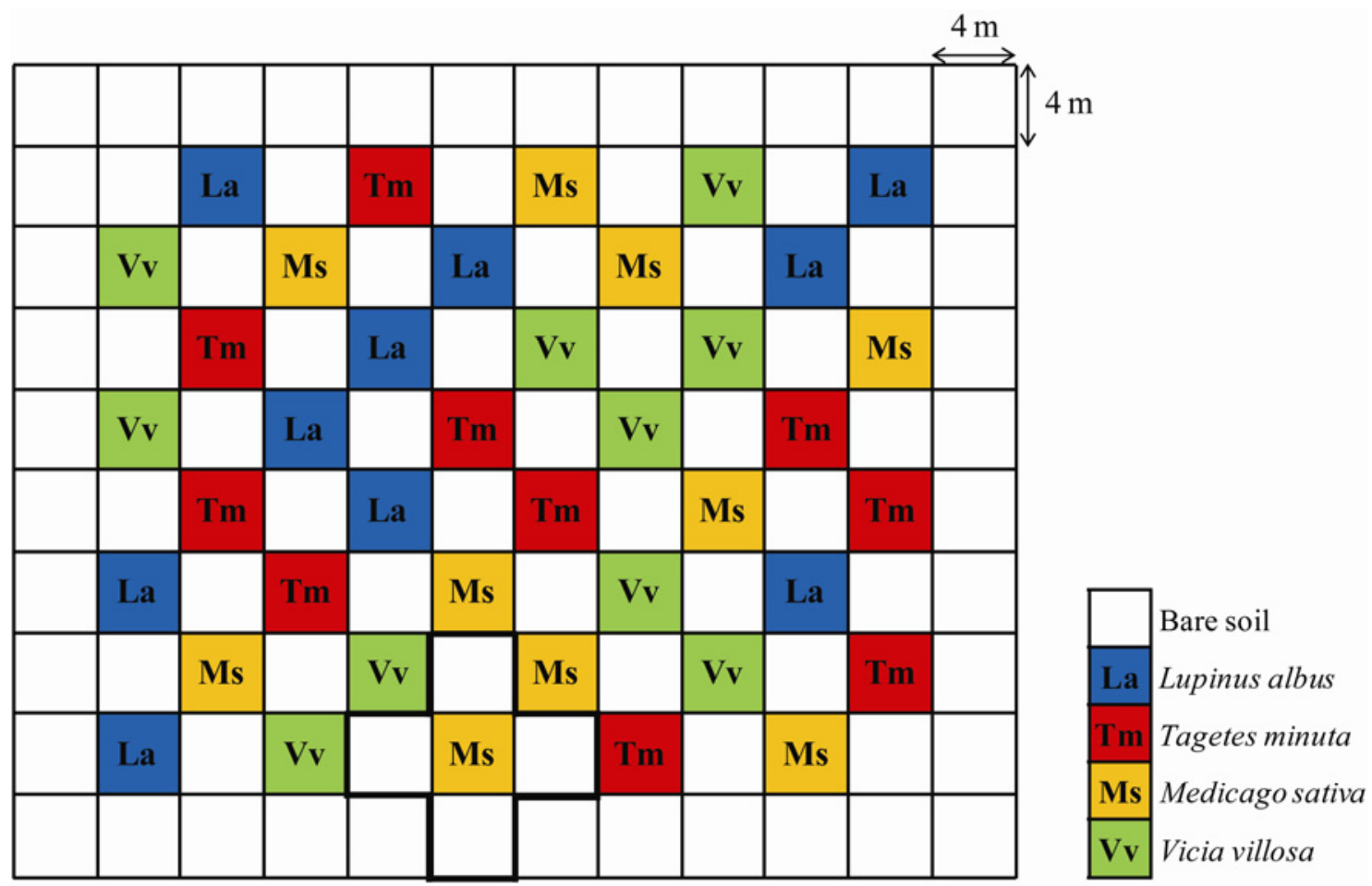

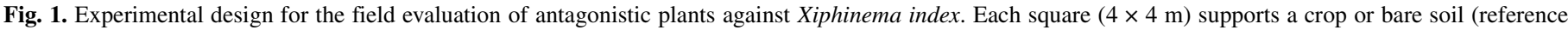

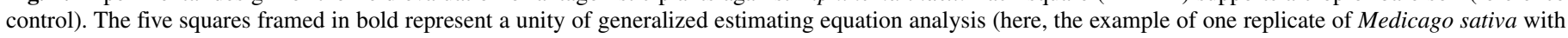
the four surrounding reference control plots). 
after a devitalization with Glyphosate (Roundup) in autumn 2006. No nematicidal treatment had been applied. The upper soil layer was sandy gravel with low organic matter $(<0.5 \%)$ over a layer of white sand. Four preexploratory 2-liter samples revealed the presence of $0,2,8$, and $14 X$. index individuals per sample, respectively.

We designed a protocol taking into account the maximum cost associated with the sampling (from soil sampling in the field to nematodes extraction and counts in the lab), estimated at 100 sampling points. The protocol design included 10 replicates of each tested plant. In the chessboard-like arrangement, each replicate $(4 \times 4 \mathrm{~m}$ plot $)$ was surrounded with four $4 \times 4 \mathrm{~m}$ control plots (bare soil). The experimental site encompassed a total of 98 plots and measured 2,112 $\mathrm{m}^{2}$ (Fig. 1). We carried out the sowing at the end of April 2007. We made the tested plants grow over 4 months, without irrigation in order to be as close as possible to the real grapevine-growing conditions. Mechanical weeding was done in the bare soil plots all along the experiment.

Nematode sampling, extraction, and count and root measurements. Greenhouse assay. After 4 months of cultivation, we extracted nematodes from the total content of each pot as described in Villate et al. (39). Because we could not extract nematodes from all of the 130 pots on the same date, each pot was randomly taken for extraction to avoid any temporal effect on final nematode numbers over a period of 2 weeks.

Vineyard assay. We carried out the final sampling on 27 August 2007. In the center of each of the 98 plots, we dug a 1.2-m-deep and $0.5-\mathrm{m}$-wide trench with an excavating machine and recovered a 5-liter sample of soil by collecting soil clods from four to six points of the undisturbed opposite sides of the trench, at 0.5 to $0.8 \mathrm{~m}$ depth. We also measured the maximum depth reached by the roots of each plant species in each plot on the sides of the trench using a tape measure. Soil samples were stored at $20^{\circ} \mathrm{C}$ in the dark until nematode extraction. We gently mixed each 5-liter soil sample and randomly took a 2-liter subsample for nematode extraction.

In both assays, nematodes were isolated from soil samples by the Cobb's sieving and decanting method, as described in Villate et al. (39). Adults and juveniles were counted from the final suspension under a dissecting microscope.

Data analysis. Greenhouse assay. To test the plant effect on nematodes, we tested the correlation between the final nematode numbers and the modality (each plant species, grapevine or bare soil) by computing a multi-analysis of variance (ANOVA). The difference between pairs of modalities was tested using the Tukey test (95\% confidence limits). All computations and analyses were done using $\mathrm{R}$ software package 2.6.1. (27). We first built a model with the modalities grapevine, bare soil and each of the 10 plant species to test whether, as expected, nematode densities were higher in grapevine. Then, we removed the grapevine modality from our model for two reasons. First, we wanted to test whether nematode densities were affected by a treatment different from bare soil, the reference control treatment. Second, the regression curve was hence not influenced by extreme values from this modality and the model gained power in predicting expected values from the other modalities.

Vineyard assay. Analyses aimed here to test whether nematode numbers differed between bare soil plots and sown plots. Nematode numbers were analyzed against the modality (i.e., T. minuta, V. villosa, M. sativa, L. albus, or reference control) in a generalized estimating equation (GEE) model to take into account correlated data. Indeed, (i) control plots (bare soil) are shared between four modalities in our experimental design and (ii) because nematode numbers show a neighborhood structure in the soil (39), nematode number in a plot depends on the numbers in the surrounding plots. If this correlation were not taken into account,

\section{Nematode numbers}

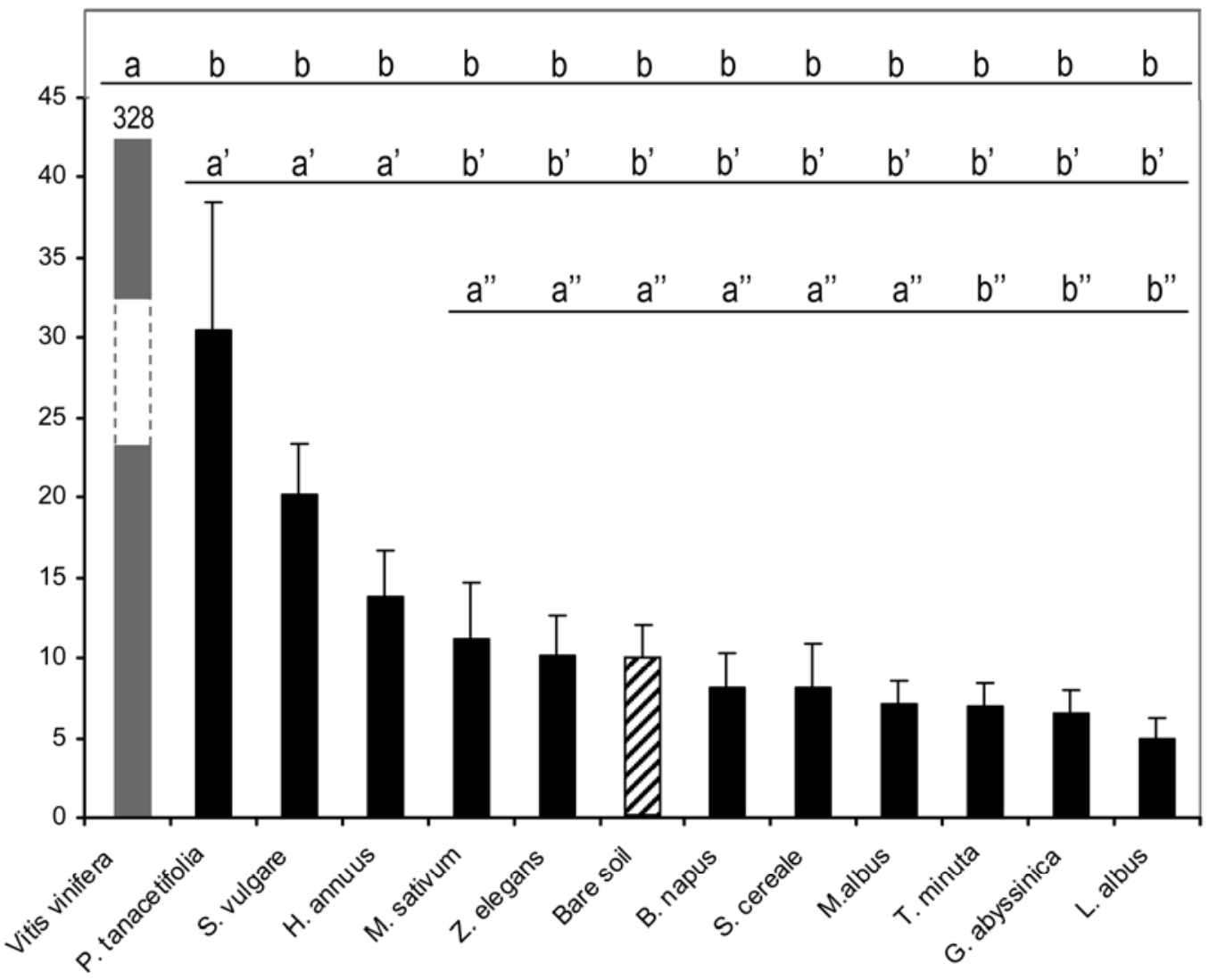

Fig. 2. Mean nematode numbers, with standard errors, observed on each modality in the 2-liter pots of the greenhouse assay (10 replicates). 
the standard errors of the parameter estimates would not be valid (for details see 24). Each of the 10 replicates of a given plant species was associated with the four surrounding control plots (Fig. 1). We used a $\log (x+1)$ transformation to normalize the data and the model assumed a Gaussian error (family = Gaussian). The variance-to-mean ratios (dispersal indices = DI) were computed to test whether nematodes were uniformly (uniform distribution; DI $<1$ ), randomly (Poisson distribution; DI $\approx 1$ ), or patchily (aggregated distribution; DI $>1$ ) distributed in bare soil plots (24). All the computations were performed with the $\mathrm{R}$ software package, version 2.6.1. (27).

\section{RESULTS}

Antagonistic effect of plants evaluated in controlled conditions. Four months ( 1 cropping cycle) after the inoculation of 200 $X$. index, surviving nematode numbers were determined. Figure 2 shows the final numbers, with standard errors, of $X$. index recovered on each plant modality, the grapevine as positive control and bare soil as reference. The ANOVA revealed a significant effect of the modality on nematode final numbers $(F=984.15$; df $=12 ; P<0.001)$. The contrast analysis performed by the Tukey test indicated that nematode numbers in grapevine were significantly higher than in each of the other modalities (estimate $<0$ and $P<0,001)$ : all plant species and bare soil had a significant negative effect on $X$. index numbers compared with grapevine. The high nematode numbers found in grapevine tended to mask the effect of other modalities. So, because we aimed to find plants with a significant negative effect on nematode numbers compared with bare soil, we excluded the grapevine modality from the next analysis (see Materials \& Methods). Without the grapevine modality, we still revealed a significant effect of the modality (each of the 10 plant species and bare soil) $(F=37.608$; $\mathrm{df}=11$;
$P<0.001)$. The Tukey test showed that final nematode numbers were significantly lower in L. albus, M. albus, G. abyssinica, and $T$. minuta compared with the reference control bare soil (estimates $<0$ and $P<0.001$ ). On the other hand, the final nematode numbers in $H$. annuus, $S$. vulgare, and $P$. tanacetifolia were significantly higher than those of the bare soil (estimates $>0$ and $P<0.05$ ), and nematode numbers in $M$. sativa, $Z$. elegans, $B$. napus, and $S$. cereale were not significantly different from bare soil. Even when excluding the three plant species showing a positive effect compared with bare soil (H. annuus, $S$. vulgare, and $P$. tanacetifolia), we still revealed a significant effect of the modality (plant species or reference control) $(F=3.8488$; $\mathrm{df}=8$; $P<0.001$ ) but only L. albus, G. abyssinica, and T. minuta showed final nematode numbers significantly lower than the bare soil (estimates $<0, P<0.001$ for $L$. albus and $P<0.05$ for $G$. abyssinica and T. minuta).

Antagonistic effect and rooting depth evaluated in vineyard conditions. After 4 months of cultivation, sampling of the 96 squares was performed and the numbers of $X$. index were evaluated in the field experiment. Nematode numbers in bare soil plots were significantly higher than those counted in sown plots

TABLE 3. Generalized estimating equations showing the effects of the plant species on nematode numbers ${ }^{\mathrm{a}}$

\begin{tabular}{lccc}
\hline & $\beta$ & $\mathrm{SE}$ & $P$ \\
\hline Intercept & 4.0258 & 0.1302 & 0.0000 \\
Lupinus albus & -0.4413 & 0.2813 & 0.1167 \\
Medicago sativa & -0.1211 & 0.3453 & 0.7257 \\
Tagetes minuta & -0.8082 & 0.2971 & 0.0065 \\
Vicia vilosa & -0.6271 & 0.3133 & 0.0453 \\
\hline
\end{tabular}

${ }^{a} \beta$, estimated regression coefficient; SE, standard error of $\beta$; and $P$, significance of $\beta$.

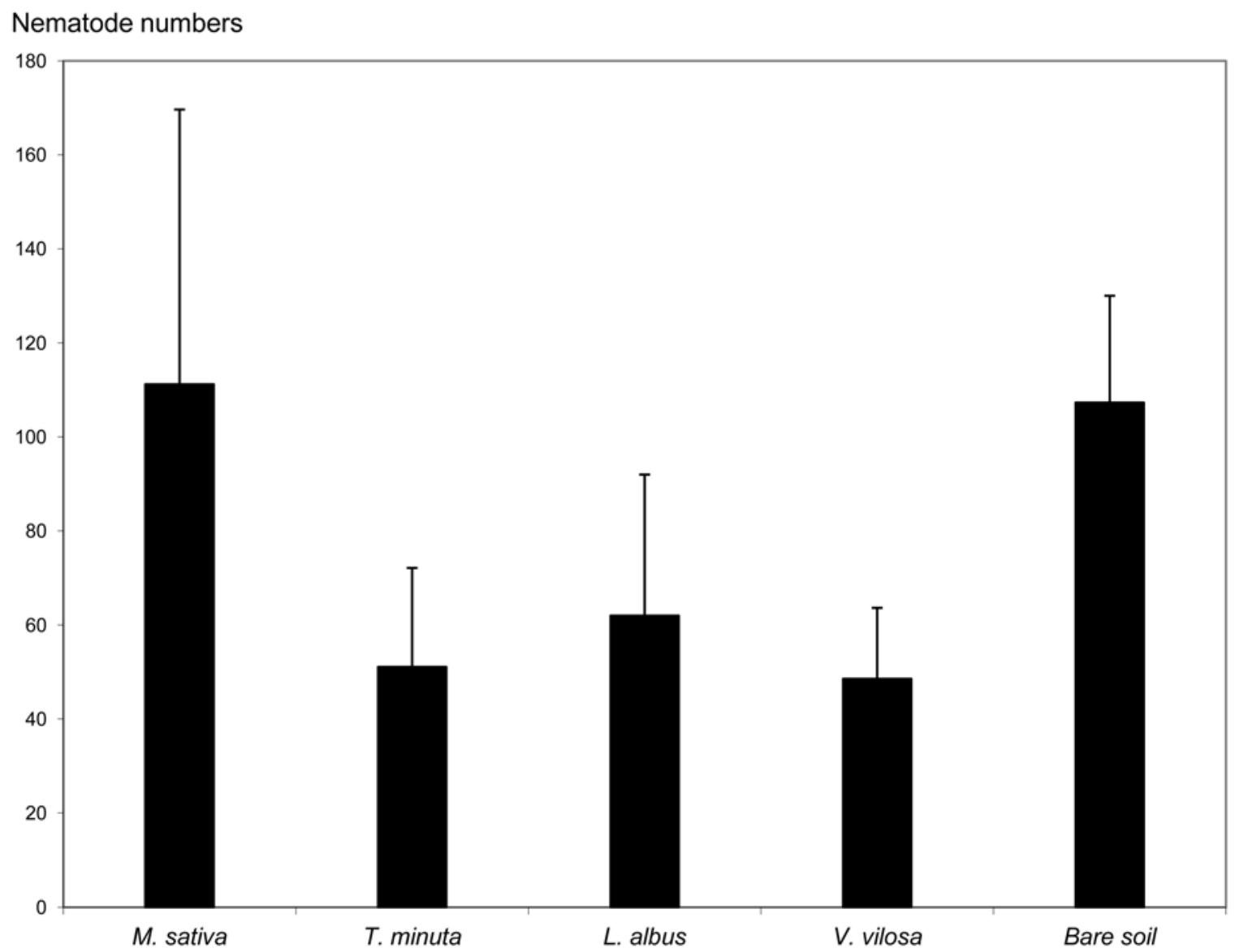

Fig. 3. Mean nematode numbers, with standard errors, sampled in the soil sown with each plant species or in bare soil from the vineyard assay (10 replicates). 
(test $=$ GEE, $\left.\chi^{2}=14.76, \mathrm{df}=4, P<0.05\right)$. GEE indicated a significant negative effect of $T$. minuta and $V$. villosa on nematode numbers, whereas $L$. albus and $M$. sativa showed a negative but nonsignificant effect (Fig. 3, Table 3). We observed a high variance of nematode numbers in plots planted with $M$. sativa (Figs. 3 and 4). Finally, we observed an aggregative spatial pattern of nematode density when taking into account only bare soil plots (Fig. 4), with DI value of $257.7(P<0.001)$. Observations of the root systems showed that $M$. sativa and $T$. minuta roots reached
70 to $80 \mathrm{~cm}$ mean depth, whereas those of L. albus and $V$. villosa only reached approximately half of this depth $(35$ to $40 \mathrm{~cm})$.

\section{DISCUSSION}

The present study aimed mainly at identifying plants that enable reducing the fallow period between two successive grapevine plantations by accelerating nematode decrease compared with bare soil. To address this issue, a panel of plant species, selected

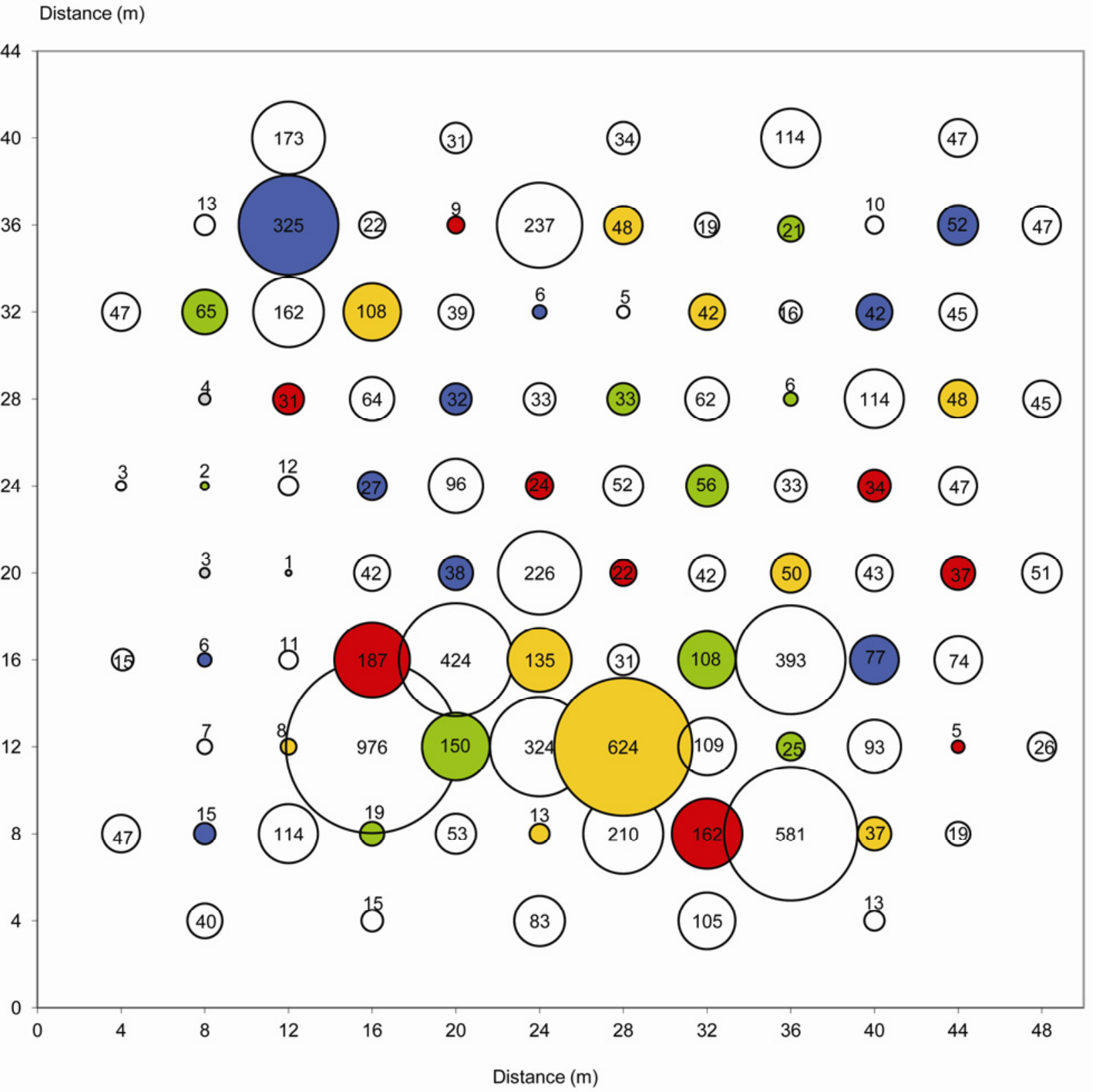

\begin{tabular}{|c|c|}
\hline & Bare soil \\
\hline $\mathrm{La}$ & Lupinus albus \\
\hline m & Tagetes minuta \\
\hline$[\mathbf{s}$ & Medicago sativ \\
\hline & Vicia villosa \\
\hline
\end{tabular}

Fig. 4. Horizontal distribution of Xiphinema index numbers in the vineyard assay. Values within circles indicate, for each plot, the numbers recovered per 2-liter soil sample. 
on their putative antagonistic effect or from previous studies (2$4,23,31,32$ ), was evaluated both in controlled conditions and in a naturally GFLV and $X$. index infested vineyard. Experiments in controlled conditions allowed an initial screening of potential antagonistic plants against $X$. index (the nematodes are exposed to a high root density), whereas assays in vineyard conditions permitted to test two of the greenhouse antagonistic plants in natural conditions together with two plants already known as agronomically well adapted under vineyard conditions. To our knowledge, the present study is the first report evaluating plants in both controlled and field conditions.

In the controlled greenhouse experiment, our study showed that M. albus, L. albus, T. minuta, and G. abyssinica significantly reduced nematode numbers compared with bare soil. The final $X$. index numbers in presence of $H$. annuus, $S$. vulgare, and $P$. tanacetifolia were significantly higher than those of the bare soil, even though they were lower than in grapevine, the natural host of $X$. index. Medicago sativa, Z. elegans, B. napus, and S. cereale displayed no significant change compared with bare soil. In the novel experimental design conducted in vineyard, 4 months of marigold ( $T$. minuta) and hairy vetch ( $V$. villosa) cultivation significantly reduced nematode densities compared with bare soil.

Previous studies already revealed an antagonistic effect of some plant species against $X$. index. They showed both significant and nonsignificant negative effects of $Z$. elegans and B. napus, depending on the type of application (Table 1). Z. elegans reduced nematode numbers when applied as aqueous extracts (23) but not as green manure in a field experiment (2), whereas B. napus showed an antagonistic effect as green manure in the field (2) but not in greenhouse (4). In our greenhouse assay, neither Z. elegans nor B. napus showed a significant antagonistic effect compared with bare soil. However, both species seem moderate hosts as nematode numbers recovered from both species are significantly lower than in grapevine, the natural host of $X$. index. On the other hand, we revealed an antagonistic effect of T. minuta, L. albus, and $G$. abyssinica in controlled conditions, whereas these plants did not show any significant effect on nematode numbers when applied as green manure in previous field studies (2).

In the vineyard assay, marigold $T$. minuta also significantly reduced $X$. index numbers compared with bare soil. This result is consistent with the well-known nematicidal effect of marigold against various nematode species $(17,26,29)$. Marigold showed good growth vigor and produced abundant roots reaching deep layers where highest nematode numbers are mostly located. By contrast, the hairy vetch, which also showed a significant antagonistic effect in vineyard, rooted significantly less deeply (35 to $40 \mathrm{~cm}$ ) and thus appeared unable to reach the soil layers where most of the nematodes are located. These elements indicate the importance of unraveling the mechanisms of the antagonistic activity of the plants to $X$. index. Our experimental approach conducted in vineyards clearly showed that, used as a cover crop, both plants significantly reduce nematode densities compared with bare soil.

Globally, a negative effect of a plant may be due to a direct action towards the nematodes through root compounds or exudates which could be biocidal or interfere in their life cycle $(10,17,18,33)$. Nevertheless other hypotheses may be proposed. Among them a negative physical effect of the plant cannot be excluded. The plant roots absorb water, drastically decreasing soil humidity, and thus disfavor nematode survival, even though a part of the individuals may enter in a quiescent status as observed by Dalmasso (11) in the sympatric $X$. mediterraneum species. As $X$. index occurs deep in the soil, deep-rooting plants used as cover crops appear the most appropriate application form (but $V$. villosa showed significant effects in spite of shallow rooting). By contrast, antagonistic plants used as green manure, even though they may release active compounds incorporated into the soil, are less likely to have an effect as, after incorporation, they will still not reach the deep nematode individuals.

The spatial distribution pattern of $X$. index has been studied previously in naturally infested vineyard (39). We confirmed this pattern in the present study. When taking into account only bare soil plots, we revealed a significant aggregative pattern. The aggregative pattern and the neighborhood structure of nematode densities are an important constraint that must be considered in vineyard experiment designs to propose appropriate protocol and sampling designs (39). Moreover, sampling Xiphinema nematodes in grapevine fields often requires an excavating machine, is very time consuming, and may disturb the soil structure of the field. Nevertheless, field experiments, whatever their objectives, have to fit with these limiting factors and to consider the maximum sampling cost that they can support. Taking into account all these constraints, we have proposed here a novel design that allowed, completed by a GEE analysis, to overcome these major difficulties and to get a reliable evaluation of the antagonistic effect of plant species. This novel and original design, as well as the statistical analysis we proposed here, could be applied to other soil pests and pathogens, in particular other nematodes and fungi.

This design might still be improved given that reference control plots were disposed regularly whereas plants were disposed randomly. By keeping the same maximum sampling cost (100), we could set randomly both reference control and plant species plots. This procedure should permit to calculate data all together and thus will reduce the number of reference control plots and will increase the possible number of replicates per plant species or the number of species tested in a single experiment.

Most studies on the antagonistic effect of plants against nematodes, and particularly $X$. index, were limited to in vitro or greenhouse experiments. Such experiments are useful as initial screening but cannot be conclusive on the effect in vineyard field conditions. Our experimental design successfully accounted for the complexity of testing such plants in vineyard conditions, because of the field constraints related to a soil dwelling pest and unfavorable pedoclimatic conditions. Our results clearly showed that marigold and hairy vetch had a negative effect on the survival of the vector nematode $X$. index under field conditions and are promising candidates in the context of biological control of the nematode vector of GFLV. Hairy vetch is already used as cover crop since it grows well on these soils and fixes nitrogen between two successive grapevines and is adapted to a wide range of soil types. Moreover, its cultivation could be still optimized by autumn sowing to allow the plant to root deeper.

Given the complexity of this system, it clearly appears useful to test these and other plants (preselected in pot experiments) on various types of soil as well as in different vine-growing conditions.

\section{ACKNOWLEDGMENTS}

We thank the estates and their vineyard managers that have funded this research, especially the Château owner of the field. We also thank B. Chauvin for his contribution to sampling; S. Dumitrasco and L. Guayroso for help in greenhouse assays; O. Lavialle and J.-P. Da Costa for advices in the experimental design; Y. Outreman and V. Fievet for help in statistical analyses; and P. Gratadou (Jouffray-Drillaud Seeds) for providing plant seeds for our experiments.

\section{LITERATURE CITED}

1. Aballay, E., Flores, P., and Insunza, V. 2001. Nematicidal effect of eight plant species on Xiphinema americanum sensu lato in Vitis vinifera, var. Cabernet Sauvignon in Chile. Nematropica 31:95-102.

2. Aballay, E., and Insunza, V. 2002. Evaluation of plants with nematicidal properties in the control of Xiphinema index on table grapes cv. Thompson Seedless in the central zone of Chile. Agric. Tecnica 62:357-365.

3. Aballay, E., Parraguez, A., and Insunza, V. 2005. Nematicidal evaluation of five plant species incorporated into the soil as organic matter on the population of Xiphinema index in Vitis vinifera L. cv. Thompson Seedless. 
Fitopatología 40:35-42.

4. Aballay, E., Sepúlveda, R., and Insunza, V. 2004. Evaluation of five nematode-antagonistic plants used as green manure to control Xiphinema index Thorne et Allen on Vitis vinifera L. Nematropica 34:45-51.

5. Abawi, G. S., and Widmer, T. L. 2000. Impact of soil health management practices on soilborne pathogens, nematodes and root diseases of vegetable crops. Appl. Soil Ecol. 15:37-47.

6. Andret-Link, P., Laporte, C., Valat, L., Ritzenthaler, C., Demangeat, G., Vigne, E., Laval, V., Pfeiffer, P., Stussi-Garaud, C., and Fuchs, M. 2004. Grapevine fanleaf virus: Still a major threat to the grapevine industry. J. Plant Pathol. 86:183-195.

7. Bais, H. P., Weir, T. L., Perry, L. G., Gilroy, S., and Vivanco, J. M. 2006. The role of root exudates in rhizosphere interactions with plants and other organisms. Annu. Rev. Plant Biol. 57:233-266.

8. Bano, M., Anver, S., Tiyagi, S. A., and Alam, M. M. 1986. Evaluation of nematicidal properties of some members of the Family Compositae. Int. Nematol. Network Newsl. 3:10.

9. Brown, D. J. F., and Weischer, B. 1998. Specificity, exclusivity and complementarity in the transmission of plant virus parasitic nematodes: An annotated terminology. Fundam. Appl. Nematol. 21:1-11.

10. Chitwood, D. J. 2002. Phytochemical based strategies for nematode control. Annu. Rev. Phytopathol. 40:221-249.

11. Dalmasso, A. 1970. Influence directe de quelques facteurs écologiques sur l'activité biologique et la distribution des espèces françaises de la famille des Longidoridae (Dorylaimida). Ann. Zool. Ecol. Animale 2:163-200.

12. Demangeat, G., Voisin, R. Minot, J. C., Bosselut, N., Fuchs, M., and Esmenjaud, D. 2005. Survival of Xiphinema index in vineyard soil and retention of Grapevine fanleaf virus over extended time in the absence of host plants. Phytopathology 95:1151-1156.

13. Descottes, A., and Moncomble, D. 1995. Lutte contre le court-noué. Le Vigneron Champenois 9:20-24.

14. Esmenjaud, D. 2008. Les nématodes de la vigne. Pages 21-45 in: Ravageurs de la Vigne. S. Kreiter, ed. Editions Féret, Bordeaux, France.

15. Esmenjaud, D., Walter, B., Valentin, G., Guo, Z. T., and Cluzeau, D. 1992. Vertical distribution and infectious potential of Xiphinema index (Thorne et Allen, 1950) (Nematoda, Longidoridae) in fields affected by Grapevine fanleaf virus in vineyards in the Champagne region of France. Agronomie 12:395-399.

16. Gommers, F. J. 1973. Nematicidal Principles in Compositae. Mededelingen Landbouwhogeschool Wageningen.

17. Gommers, F. J., and Bakker, J. 1988. Mode of action of alpha-terthienyl and related compounds may explain the suppressant effect of Tagetes species on populations of free living endoparasitic plant nematodes. Pages 61-69 in: Chemistry and Biology of Naturally Occurring Acetylene and Related Compounds. Bioactive Molecules, Vol. 7. J. Lam et al., eds. Elsevier Science Publishers, Amsterdam.

18. Gommers, F. J., and Bakker, J. 1988. Physiological diseases induced by plant responses or products. Pages 3-22 in: Diseases of Nematodes, Vol. I. G. O. Poinar, Jr., and H. B. Jansson, eds. CRC Press, Boca Raton, FL.

19. Halbrendt, J. M. 1996. Allelopathy in the management of plant-parasitic nematodes. J. Nematol. 28:8-14.

20. Hasan, A. 1992. Allelopathy in the management of root-knot nematodes. Pages 413-441 in: Allelopathy: Basic and Applied Aspects. S. J. H. Rizvi and V. Rizvi, eds. Chapman and Hall, London, UK.

21. Heinicke, D., and Warnecke, H. 1994. Biological control with deliberate land planting. Zuckerrube 43,3:175-178.

22. Hewitt, W. B., Raski, D. J., and Goheen, A. C. 1958. Nematode vector of soil-borne fanleaf virus of grapevines. Phytopathology 48:586-595.

23. Insunza, V., Aballay, E., and Macaya, J. 2001. Nematicidal activity of aqueous plant extracts on Xiphinema index. Nematol. Mediter. 29:35-40.

24. Liang, K. Y., and Zeger, S. L. 1986. Longitudinal data-analysis using generalized linear-models. Biometrika 73:13-22.

25. Madden, L. V., and Hughes, G. 1995. Plant-disease incidence-Distribution, heterogeneity, and temporal analysis. Annu. Rev. Phytopathol. 33:529-564.

26. Ploeg, A. T. 2002. Effects of selected marigold varieties on root-knot nematodes and tomato and melon yields. Plant Dis. 86:505-508.

27. R Development Core Team 2006. R: A language and environment for statistical computing. R Foundation for Statistical Computing, Vienna, Austria.

28. Raski, D. J., Goheen, A. C., Lider, L. A., and Meredith, C. P. 1983. Strategies against grapevine fanleaf virus and its nematode vector. Plant Dis. 67:335-339.

29. Reynolds, L. B., Potter, J. W., and Ball-Coelho, B. R. 2000. Crop rotation with Tagetes sp. is an alternative to chemical fumigation for control of root-lesion nematodes. Agron. J. 92:957-966.

30. Rodriguez-Kabana, R., and Canullo, G. H. 1992. Cropping systems for the management of phytonematodes. Phytoparasitica 20:211-224.

31. Sasanelli, N. 1992. Nematicidal activity of aqueous extracts from leaves of Ruta graveolens on Xiphinema index. Nematol. Mediter. 20:53-55.

32. Sasanelli, N., and Catalano, L. 1991. In vitro nematicidal activity of aqueous extracts from pods of Capsicum annuиm (chilli pepper) on Xiphinema index. Inform. Fitopatol. 41:55-56.

33. Sukul, N. C. 1994. Control of plant-parasitic nematodes by plantsubstances. Pages 183-211 in: Allelopathy in Agriculture and Forestry. S. S. Narwal and P. Tauro, eds. Scientific Publishers, Jodhpur, India.

34. Taba, S., Sawada, J., and Moromizato, Z. I. 2008. Nematicidal activity of Okinawa Island plants on the root-knot nematode Meloidogyne incognita (Kofoid and White) Chitwood. Plant Soil 303(1-2):207-216.

35. Taylor, C. E., and Brown, D. J. F. 1997. Nematode Vectors of Plant Viruses. CAB International, Wallingford, UK.

36. Taylor, C. E., and Robertson, W. M. 1970. Sites of virus retention in the alimentary tract of the nematode vectors, Xiphinema diversicaudatum (Micol.) and X. index (Thorne and Allen). Ann. Appl. Biol. 66:375-380.

37. Thomason, I. J., and McKenry, M. 1975. Chemical control of nematode vectors of plant viruses. Pages 423-438 in: Nematode Vectors of Plant Viruses. F. Lamberti, C. E. Taylor, and W. Seinhorst, eds. CAB International, Wallingford, UK.

38. Torregrosa, L., and Bouquet, A. 1995. In vitro propagation of Vitis $\times$ Muscadinia hybrids by microcuttings or axillary budding. Vitis $34: 237-$ 238.

39. Villate, L., Fievet, V., Hanse, B., Delemarre, F., Plantard, O., Esmenjaud, D., and van Helden, M. 2008. Spatial distribution of the dagger nematode Xiphinema index and its associated Grapevine fanleaf virus in French vineyard. Phytopathology 98:942-948.

40. Zeger, S. L., and Liang, K. Y. 1986. Longitudinal data-analysis for discrete and continuous outcomes. Biometrics 42:121-130. 